University of Nebraska - Lincoln

DigitalCommons@University of Nebraska - Lincoln

Faculty Papers and Publications in Animal

Science

Animal Science Department

August 1991

\title{
Direct responses to selection for increased litter size, decreased age at puberty, or random selection following selection for ovulation rate in swine
}

\author{
W. R. Lamberson \\ University of Missouri, Columbia \\ R. K. Johnson \\ University of Nebraska-Lincoln, rjohnson5@unl.edu \\ D. R. Zimmerman \\ University of Missouri, Columbia \\ T. E. Long \\ Animal Genetic and Breed Unit, University of New England, Armidale, New South Wales, 2351, Australia
}

Follow this and additional works at: https://digitalcommons.unl.edu/animalscifacpub

Part of the Animal Sciences Commons

Lamberson, W. R.; Johnson, R. K.; Zimmerman, D. R.; and Long, T. E., "Direct responses to selection for increased litter size, decreased age at puberty, or random selection following selection for ovulation rate in swine" (1991). Faculty Papers and Publications in Animal Science. 90.

https://digitalcommons.unl.edu/animalscifacpub/90

This Article is brought to you for free and open access by the Animal Science Department at DigitalCommons@University of Nebraska - Lincoln. It has been accepted for inclusion in Faculty Papers and Publications in Animal Science by an authorized administrator of DigitalCommons@University of Nebraska - Lincoln. 
Published in Journal of Animal Science, Vol 69, Issue 8 (1991), pp. 3129-3143. Copyright (C) 1991 by American Society of Animal Science. Used by permission.

\title{
Direct responses to selection for increased litter size, decreased age at puberty, or random selection following selection for ovulation rate in swine
}

\author{
W. R. Lamberson, University of Missouri, Columbia \\ R. K. Johnson, University of Nebraska-Lincoln \\ D. R. Zimmerman, University of Missouri, Columbia \\ T. E. Long, Animal Genetic and Breed Unit, University of New England, \\ Armidale, New South Wales, 2351, Australia
}

\begin{abstract}
Nine generations of selection for high ovulation rate were followed by two generations of random selection and then eight generations of selection for increased litter size at birth, decreased age at puberty, or continued random selection in the high ovulation rate line. A control line was maintained with random selection. Line means were regressed on generation number and on cumulative selection differentials to estimate responses to selection and realized heritabilities. Genetic parameters also were estimated by mixedmodel procedures, and genetic trends were estimated with an animal model. Response to selection for ovulation rate was about 3.7 eggs. Response in litter size to selection for ovulation rate was $.089+/-.058$ pigs per generation. Average differences between the high ovulation rate and control lines over generations 10 to 20 were 2.86 corpora lutea and .74 pigs ( $\mathrm{P}$ less than .05 ). The regression estimate of total response to selection for litter size was 1.06 pigs per litter (P less than .01 ), and the realized heritability was $.15+/-.05$. When the animal model was used, the estimate of response was .48 pigs per litter. Total response in litter size to selection for ovulation rate and then litter size was estimated to be 1.8 and 1.4 pigs by the two methods. Total response to selection for decreased age at puberty was estimated to be $-15.7 \mathrm{~d}$ (P less than .01 ) when data were analyzed by regression (realized heritability of $.25+/-.05$ ) and $-17.1 \mathrm{~d}$ using the animal model. No changes in litter size occurred in the line selected for decreased age at puberty. Analyses by regression methods and mixed-model procedures gave similar estimates of responses and very similar estimates of heritabilities.
\end{abstract}




\title{
DIRECT RESPONSES TO SELECTION FOR INCREASED LITTER SIZE, DECREASED AGE AT PUBERTY, OR RANDOM SELECTION FOLLOWING SELECTION FOR OVULATION RATE IN SWINE1
}

\author{
W. R. Lamberson ${ }^{2}$, R. K. Johnson ${ }^{3}$ \\ Dwane R. Zimmerman ${ }^{3}$ and T. E. Long 4 \\ University of Nebraska, Lincoln 68583-0908
}

\begin{abstract}
Nine generations of selection for high ovulation rate were followed by two generations of random selection and then eight generations of selection for increased litter size at birth, decreased age at puberty, or continued random selection in the high ovulation rate line. A control line was maintained with random selection. Line means were regressed on generation number and on cumulative selection differentials to estimate responses to selection and realized heritabilities. Genetic parameters also were estimated by mixedmodel procedures, and genetic trends were estimated with an animal model. Response to selection for ovulation rate was about 3.7 eggs. Response in litter size to selection for ovulation rate was $.089 \pm .058$ pigs per generation. Average differences between the high ovulation rate and control lines over generations 10 to 20 were 2.86 corpora lutea and .74 pigs $(P<.05)$. The regression estimate of total response to selection for litter size was 1.06 pigs per litter $(P<.01)$, and the realized heritability was $.15 \pm .05$. When the animal model was used, the estimate of response was .48 pigs per litter. Total response in litter size to selection for ovulation rate and then litter size was estimated to be 1.8 and 1.4 pigs by the two methods. Total response to selection for decreased age at puberty was estimated to be $-15.7 \mathrm{~d}(P<.01)$ when data were analyzed by regression (realized heritability of $.25 \pm .05$ ) and $-17.1 \mathrm{~d}$ using the animal model. No changes in litter size occurred in the line selected for decreased age at puberty. Analyses by regression methods and mixed-model procedures gave similar estimates of responses and very similar estimates of heritabilities. Key Words: Pigs, Selection, Ovulation, Litter Size, Puberty
\end{abstract}

J. Anim. Sci. 1991. 69:3129-3143

\section{Introduction}

Improvement of reproductive traits will improve efficiency of swine production (Tess et al., 1983). Few results of selection experi-

\footnotetext{
${ }^{1}$ Journal Paper No. 9236 of the Nebraska Agric. Exp. Sta. We appreciate the assistance of Dale Van Vleck with REML analyses of these data. P. J. Cunningham made a major contribution in planning and design of the experiment.

${ }_{2}$ Anim. Sci. Dept., Univ, of Missouri, Columbia.

${ }^{3}$ Anim. Sci. Dept., Univ. of Nebraska, Lincoln.

${ }^{4}$ Anim. Gen. and Breed Unit, Univ. of New England, Armidale, New South Wales, 2351, Australia.

Received June 25, 1990.

Accepted February 15, 1991.
}

ments to improve reproductive traits in swine are available. Two experiments with intent of increasing litter size had promising early results (Ollivier, 1973; Zimmerman and Cunningham, 1975), but early trends did not persist into later generations (Cunningham et al., 1979; Ollivier and Bolet, 1981; Ollivier, 1982).

Selection for increased litter size has been effective in mice (Bradford, 1968; Falconer, 1971; Joakimsen and Baker, 1977); thus, one might also expect it to be effective in swine. Selection for increased ovulation rate in mice was directly effective but did not immediately result in increased litter size (Bradford, 1969; Land and Falconer, 1969). However, Bradford 
(1969) reported that litter size increased in generations 10 to 15 of selection for increased ovulation rate and additional response in litter size occurred after selection for ovulation rate was relaxed. The potential to increase litter size in swine by selecting for increased ovulation rate or by selecting for increased ovulation rate and then for large litters needs to be investigated.

Hixon et al. (1987) successfully selected for increased and decreased age at puberty, but the experiment was small, and only one generation of selection was practiced. Divergent selection for age at vaginal opening, a trait correlated with puberty, was effective in mice (Drickamer, 1981); however, no experiments in which selection was directly for early age at puberty in mice have been reported. Responses to selection for decreased age at puberty in swine need to be investigated.

The objectives of this study with pigs were to estimate 1) responses in litter size to selection for increased ovulation rate, 2) responses in litter size and ovulation rate to relaxation of selection for increased ovulation rate, 3) response to direct selection for increased litter size in a line previously selected for high ovulation rate, and 4) response to selection for decreased age at puberty.

\section{Materlals and Methods}

\section{Population and Management}

The study was conducted with the Nebraska Gene Pool population, a 14-breed composite that was closed in 1965. Lines selected for high ovulation rate (OR) or randomly (C) were established in 1967 (Zimmerman and Cunningham, 1975) and continued for nine generations (Cunningham et al., 1979). Throughout this first phase of the experiment, lines were maintained with approximately 40 litters by 15 sires per generation. During selection for ovulation rate, the population was located at the University of Nebraska swine research center at Lincoln.

After their first litters were weaned, selected generation- 8 dams of the OR line were mated to selected generation-8 boars. The progeny of these parents were used to develop a line (RS) in which selection for ovulation rate was relaxed. The same system of mating selected parents from generation 8 was used in line $C$.
Progeny from the second-parity sows of both lines were delivered by Caesarean section and placed in new facilities at the University of Nebraska, Lincoln, Agricultural Research and Development Center, Mead, NE. At least one gilt per litter and two boars per half-sib family (one designated as a breeder and the other as an altemate) were moved to the Agricultural Research and Development Center. These boars and gilts were randomly mated within line to produce generation 10 . A total of 32 litters were bom in the $\mathrm{C}$ line and 26 litters were born in the RS line in generation 10. In each line, one boar per half-sib family was used as a breeder, and all gilts were retained for breeding. They were randomly mated to produce generation-11 progeny, which were used to initiate the second phase of the experiment.

The second selection phase, illustrated in Figure 1, began with progeny from generation 11. Litters of weanling pigs from the RS line were randomly assigned to lines to be selected for decreased age at first estrus (AP), increased litter size at birth (LS), or randomly (RS). Litters were assigned to lines on the basis of pedigree of dam. Seventy-four litters were born in generation 11 in the OR line. Dams of these litters were from 23 litters by 15 sires produced in generation 10. Litters of dams that were full-sisters were randomly assigned to the AP, LS, or RS lines. Eighteen of the 23 fullsib families of dams were represented by three or more gilts and contributed to each line. The 74 base-generation litters also were sired by 15 boars, one per paternal half-sib family. All 15 maternal grandsire and sire half-sib families were represented in each line.

Eighty-six litters were born in the $\mathrm{C}$ line in generation 11. Fifty-five of these litters were randomly selected, with the stipulation that there be at least one from each half-sib family, and one gilt was randomly selected from each of these litters. These gilts were mated to 15 randomly selected boars, one per half-sib family, to continue the $\mathrm{C}$ line.

Eight generations of selection for litter size and age at puberty were completed. Selection was initiated among generation-11 progeny based on size of the litter in which pigs were born or gilt's age at first estrus, respectively, in the $L S$ and AP lines. Selections in the RS and $C$ lines were random.

Swine were managed in confinement. In large litters, the number of pigs nursing sows 


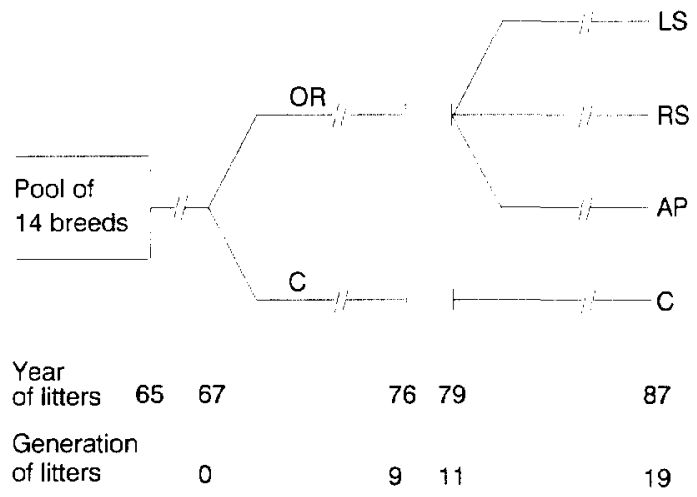

Figure 1. History of selection in Nebraska gene pool population: Generation $=$ generation of progeny, $\mathrm{OR}=$ ovulation rate, $\mathrm{LS}=$ litter size, $\mathrm{RS}=$ relaxed selection, AP $=$ age at puberty, and $C=$ control. See text for details of formation of lines.

was reduced at farrowing by transferring pigs to sows with small litters. Pigs to be transferred to another litter were chosen randomly. Crossfostering of pigs was done within lines to the extent possible, but some transfers were across lines. The number of pigs reared in a litter was no more than 10 for most litters. Pigs were weaned at $28 \mathrm{~d}$ of age and transferred to nursery pens in groups of 25. At approximately $56 \mathrm{~d}$ of age, selected pigs were moved to modified open-front buildings in single-sex groups of 10 , where they remained until breeding age. Females from the $C$ and LS lines and all males were placed in one unit. Females from the RS and AP lines were placed in another unit and were not exposed to boars until they were observed for estrus.

Gilts were fed a balanced diet with either corn or sorghum and soybean meal as major ingredients. A diet formulated to contain $16 \%$ CP was fed to all pigs from $56 \mathrm{~d}$ of age to approximately $60 \mathrm{~kg}$, and a diet with $14 \% \mathrm{CP}$ was fed thereafter. Gilts were given ad libitum access to feed until they weighed approximately $90 \mathrm{~kg}$. From that point until approximately $14 \mathrm{~d}$ before mating, a daily ration of feed averaging $2.25 \mathrm{~kg}$ per gilt was delivered to each pen. Daily intake was increased to 2.7 to $3 \mathrm{~kg} / \mathrm{d}$ for $14 \mathrm{~d}$ before mating. During gestation, gilts were individually fed about $\mathbf{1 . 8}$ $\mathrm{kg} / \mathrm{d}$ for the first $90 \mathrm{~d}$ and then $2.7 \mathrm{~kg} / \mathrm{d}$ until parturition.

All selections, except those of females in the AP line, were made while pigs were in the nursery. Selections in the C, RS, and LS lines included 55 females each generation. Thirty boars were selected in all lines each generation. In the RS and $C$ lines, females were selected randomly, with the stipulation that there be at least one per litter if one existed, and two boars were randomly selected from each half-sib family (one was designated as a breeder, the other as an alternate).

Males in the AP line were selected as in the RS and C lines. Females were selected based on their age at first estrus, defined as the age when a gilt would first stand firmly for a mount by a boar. Detection of estrus was accomplished by exposing each pen of gilts to a mature, intact boar for a 15 -min period each day. Observations began when the oldest gilt in a pen reached $135 \mathrm{~d}$ of age in generations 11 to $15,130 \mathrm{~d}$ of age in generation 16 , and $125 \mathrm{~d}$ of age thereafter; these were generations 0 to 4,5 , and 6 to 8 of selection for AP. Daily observation of gilts was continued until all gilts had been observed to be in estrus or until the youngest gilt of a generation was $250 \mathrm{~d}$ of age. Records for gilts not observed in estrus were not considered in analyses. The total numbers of gilts not observed in estrus were 15 out of 1,146 in the AP line and 6 out of 439 in the RS line.

The criterion for selection within the LS line was the number of fully formed pigs in the animal's birth litter. Two males, one designated as a breeder and one as an altemate, from each of the 15 largest litters and up to four, but in most cases no more than three, females from each of the 17 largest litters were selected.

Each generation, 50 females and 15 males from each line were moved from the modified open-front buildings to a confinement breeding-and-gestation building. From observations on age at puberty for the RS and AP lines, it was determined that nearly all gilts were mated at their third, fourth, or fifth estrous period, but a small number were mated at their second or sixth estrous period. Full- and half-sib matings were avoided; otherwise, matings were random. A system of hand mating was used, and gilts were maintained in stalls during the gestation period.

\section{Statistical Analyses}

Selection for Ovulation Rate. Cunningham et al. (1979) reported correlated response in litter size to selection for ovulation rate. They 
used data from generations 0 through 9. However, gilts measured for litter size in generation 0 were selected for ovulation rate, and this was not considered in their analyses. Also, more data are now available for generation 9 because second matings of selected generation-8 sows and boars produced generation-9 females that farrowed at the Agricultural Research and Development Center.

Data were analyzed including litters from generation -1 , for which dams were not selected, and the second measure of generation 9 to determine response in litter size to selection for ovulation rate. Line-generation means weighted by the number of observations per mean were regressed on generation number, and the difference between regressions for the $O R$ and $C$ lines was used to estimate response to selection.

Relaxed Selection for Ovulation Rate. Because the RS and LS lines both were formed from the OR line, it was first necessary to determine genetic changes in litter size during the period of relaxed selection in the RS line to determine whether the RS line, the $C$ line, or both of these lines were appropriate controls for measuring response in the LS line. Selection for litter size was terminated after eight generations (generation-18 dams). All lines then went into an evaluation period, during which they were maintained with random selection and mating. Thus, lines RS and $\mathrm{C}$ were mated randomly from generations 10 to 20 and means for these generations for the RS and C lines were used to estimate response in litter size to relaxed selection for ovulation rate. Means weighted by number of observations per mean were regressed on generation number.

Selection for Litter Size and Age at Puberty. Traits considered were litter size in all lines and age at puberty in the RS and AP lines. Means weighted by number of observations per mean were regressed on generation number within each line. Realized heritability for litter size was estimated by regressing generation means of the LS, RS, and C lines on cumulative selection differential, weighted by number of offspring, while simultaneously fitting generation number (Richardson et al., 1968).

Selection differentials for litter size for gilts and boars selected in generation 11 (generation 0 of the second phase) were calculated as deviations of size of litter born in from the mean of all 74 litters for the AP, RS, and LS lines and from the mean of all 86 litters for the C line. In subsequent generations, selection differentials were calculated from the respective line-generation mean. Cumulative selection differentials (CSD) for litter size for generation $n$ were calculated as follows: $\operatorname{CSD}_{\mathbf{n}}$ $=\sum_{i=0}^{n-2} .5\left(M_{i}+F_{i}\right)+F_{n-1}$, where $M$ and $F$ are selection differentials of dams of selected males and females, respectively, in generation i. Selection differentials for males were calculated from the selection differential for the dam of each selected male weighted by the number of its daughters measured in the subsequent generation, and $M$, the average selection differential, was calculated. Selection differentials for females were calculated from the selection differential on each female weighted by the number of daughters that farrowed in the next generation. These selection differentials were averaged to obtain $F$, the mean selection differential.

For age at puberty, a similar procedure was used except that generation means of the AP and RS lines were used. Selection was practiced only among females, and their selection differentials were weighted by the number of daughters measured for puberty in the next generation.

Average weighted selection differentials for both litter size and age at puberty were summed to calculate cumulative selection differentials that were fitted to the following model: $Y_{i j}=a_{. .}+g_{. j}+B Z_{i j}+E_{i j}$, where $Y_{i j}=$ mean for the $j^{\text {th }}$ generation of the $i^{\text {th }}$ line, $a . .=$ the expected performance of the base population, $g_{. j}=$ the environmental effect common to each line in the $\mathrm{j}^{\text {th }}$ generation, $B=$ the linear regression coefficient on the cumulative selection differential $\left(Z_{i j}\right)$ of the $i^{\text {th }}$ line in the $j^{\text {th }}$ generation, and $\mathrm{E}_{\mathrm{ij}}=$ random error. Weighted least squares procedures were used and the weighting factor was $n_{i j}$, the number of observations in the mean for the $j^{\text {th }}$ generation and $i^{\text {th }}$ line.

Realized heritabilities were calculated as twice the regressions on CSD. Standard errors of regression coefficients and the realized heritabilities were calculated to include residual variation from the regression plus an increment due to drift variance (Hill, 1972, 1977). Calculation of drift variance was based on inbreeding accumulated since the initiation 


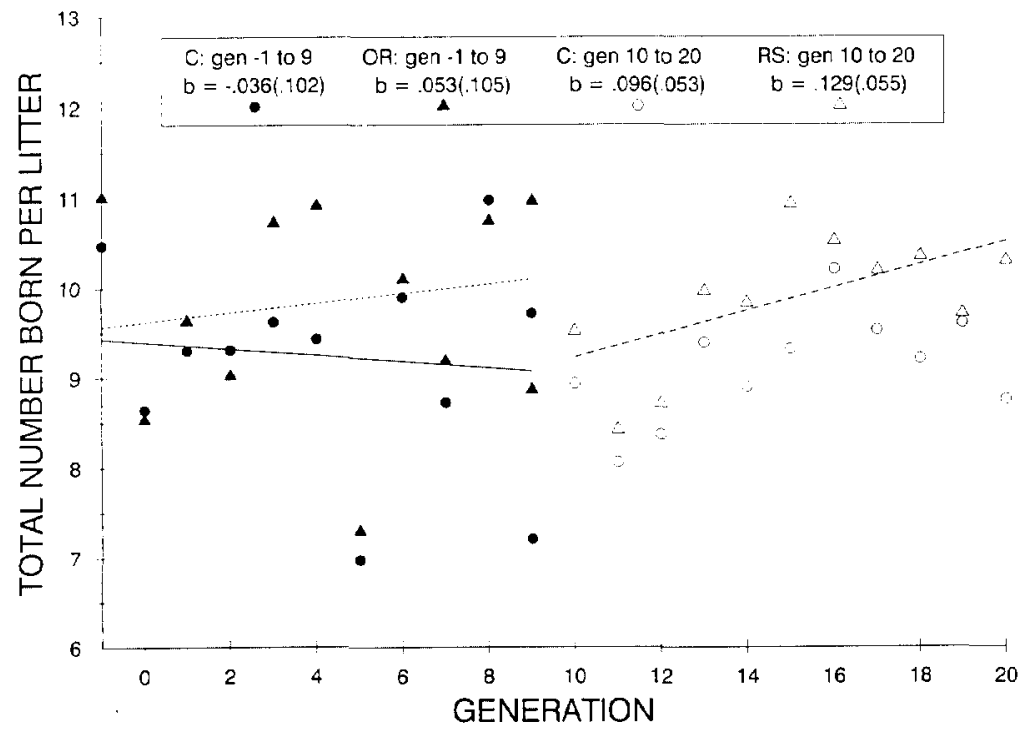

Figure 2. Means and regressions (SE) of means on generation for litter size during periods of selection for ovulation rate, generations -1 to 9 , and relaxed selection, generations 10 to $20: C=$ control line, $O R=$ ovulation rate line, and $R S=$ relaxed selection line.

of selection for litter size and age at puberty.

Mixed-Model Analyses. Data also were fitted to an animal model to estimate genetic trends. Analyses were done overall (the period from 1967 to 1987; generations 0 to 18 ) and separately for the period of selection for ovulation rate (generations 0 to 9 ) and the period of selection for litter size and age at puberty (generations 10 to 18 ). The following model was used: $\mathrm{y}=\mathrm{XB}+\mathrm{Z}_{1} \mathrm{u}_{1}+\mathrm{Z}_{2} \mathrm{u}_{2}+\mathrm{e}$, where $y=N \times 1$ vector of observations, $X=N$ $\times p$ incidence matrix, $B=p \times 1$ vector of year effects, $Z_{1}=N \times q_{1}$ matrix relating litter environmental effects to observations, $Z_{2}=N$ $\times \mathrm{q}_{2}$ matrix relating additive genetic effects to observations, $u_{1}=q_{1} \times 1$ vector of random litter environmental effects, $u_{2}=q_{2} \times 1$ vector of random effects of additive genetic merit, and $e=N \times 1$ vector of random error. Random effects were assumed to be distributed as follows: $u_{1} \sim\left(0, I \sigma_{1}^{2}\right), u_{2} \sim\left(0, A \sigma_{a}^{2}\right)$, and $e-\left(0, I \sigma^{2}\right)$, where $\sigma_{1}^{2}, \sigma_{\mathrm{a}}^{2}$, and $\sigma^{2}$ represent litter, additive genetic, and error variances, respectively; $A$ is the numerator relationship matrix calculated from generation 0 , base year of 1967 , and $I$ is the identity matrix. Covariances among random effects $u_{1}, u_{2}$, and e were assumed to be zero. Genetic effects of animals were predict- ed, average values were calculated for each line-generation, and these values were plotted to illustrate genetic trends.

Estimates of variance components were obtained by two methods. The REML procedure (Patterson and Thompson, 1971) was used for data from 1978 through 1987 . This is the preferred method because it accounts for selection. However, it is difficult to do if matrices are large and could not be accomplished on pooled data from all lines over all generations. The upper limit on number of observations that could be analyzed by REML was about 1,000 ; thus, estimates of variance components only were obtained within each line for litter size. Pseudo-expectation (Schaeffer, 1986) is an approximation to REML that can be accomplished on large data sets. Estimates of variance components were obtained by this method over all generations and separately for the first and last phases of the experiment.

\section{Results and Discussion}

Selection for Ovulation Rate. Cunningham et al. (1979) reported an average response of .44 corpora lutea per generation over nine generations of selection for ovulation rate and 
TABLE 1. OVULATION RATE OF GILTS FROM THE CONTROL LINE AND THE LINE SELECTED FOR INCREASED OVULATION RATE MEASURED DURING A PERIOD OF RANDOM SELECTION

\begin{tabular}{|c|c|c|c|c|c|}
\hline \multirow[b]{2}{*}{ Generation $^{\mathrm{a}}$} & \multicolumn{2}{|c|}{ Select } & \multicolumn{2}{|c|}{ Control } & \multirow[b]{2}{*}{ Source } \\
\hline & $\mathbf{n}$ & Mean & $\mathbf{n}$ & Mean & \\
\hline $\begin{array}{l}12(3) \\
15(6) \\
15(6) \\
18(9)\end{array}$ & $\begin{array}{l}57 \\
39 \\
35 \\
29\end{array}$ & $\begin{array}{l}16.2 \\
15.7 \\
18.5 \\
15.7\end{array}$ & $\begin{array}{l}52 \\
47 \\
23 \\
33\end{array}$ & $\begin{array}{l}14.7 \\
11.8 \\
15.3 \\
13.4\end{array}$ & $\begin{array}{l}\text { Johnson et al., } 1981 \\
\text { Lamberson, } 1984 \\
\text { Kelly et al., } 1988 \\
\text { Koenig, } 1987\end{array}$ \\
\hline
\end{tabular}

"Numbers in parentheses are generation number after relaxation of ovulation rate selection.

a difference of 3.71 corpora lutea between the $\mathrm{OR}$ and $\mathrm{C}$ lines at generation 9 . Response in litter size to selection for ovulation rate is illustrated in Figure 2. Regressions on generation were $-.036 \pm .102$ for the $C$ line and .053 \pm .105 for the OR line, when data from generation -1 and the second measure of generation 9 were included. These regressions are quite different from values of .09 and .15 for the $C$ and $O R$ lines, respectively, reported by Cunningham et al. (1979), because means for generation -1 were higher than those for generation 0 and means for the second measure of generation 9 were lower than for the first measure of generation 9. The estimate of response in litter size per generation to selection for ovulation rate is $.089 \pm .058$ pigs. This estimate is $50 \%$ higher than the value of $.06 \pm .07$ reported by Cunningham et al. (1979). However, only $20 \%(.089 / .44)$ of the average increase in ovulation rate was realized as more pigs at birth.

Fifteen generations of selection for ovulation rate in mice produced a response of four to five ova (Bradford, 1979). Response in litter size of first-parity females was $.07 \pm .05$ pups per generation through generation 11 (Bradford, 1969), but response in second-parity females was negative. Litter size did increase slowly, but significantly, after generation 10 (Bradford, 1979). Similarly, Land and Falconer (1969) reported response to selection for ovulation rate for 12 generations in mice but no increase in litter size.

Relaxed Selection for Ovulation Rate. Ovulation rate of gilts of the RS and C lines was measured in generation 12 (Johnson et al., 1981), twice in generation 15 (Lamberson, 1984; Kelly et al, 1988), and in generation 18 (Koenig, 1987). These generations correspond to three, six, and nine generations of random selection. Data are summarized in Table 1 . The difference between weighted averages in the
RS and C lines is 2.86 corpora lutea, approximately one less than Cunningham et al. (1979) found after nine generations of selection for ovulation rate.

The predicted response in litter size after nine generations of selection for ovulation rate based on the regression coefficient of .089 pigs per generation is .80 pigs per litter. The differences between the lines were 1.25 and 1.66 pigs in the first and second evaluations of generation 9, respectively.

Means for the C and RS lines for the period of relaxed selection also are plotted in Figure 2. Litter size for the RS line was larger than for the $C$ line in each of the $\mathbf{1 1}$ generations of relaxed selection (Table 2). The average difference during this period was $.74 \pm .20$ pigs per litter, very similar to the difference predicted at generation 9 .

Litter size increased for both the RS and C lines during the period of relaxed selection (Figure 2), presumably due to positive environmental trend. However, relaxed selection had little effect on differences between lines. Descriptive statistics are presented in Table 2 and regressions of line means on generation number in Figure 2. Response in the RS line above the response that occurred in the $\mathrm{C}$ line was not significant and was estimated to be $.033 \pm .048$ pigs per generation. There was no consistent pattem in differences between the $\mathrm{RS}$ and $\mathrm{C}$ lines.

Best linear unbiased predictions of breeding values for litter size of all lines beginning with the initiation of selection for ovulation rate are presented in Figure 3. This graph clearly shows a divergence in litter size between the $\mathrm{OR}$ and $\mathrm{C}$ lines, indicating that selection for increased ovulation rate increased litter size. The difference between lines in estimated breeding value was .71 pigs at generation 9 . No convergence was evident since relaxation of selection. 
TABLE 2. DESCRIPTIVE STATISTICS FOR LITTER SIZE BY LINE AND GENERATION (GEN)

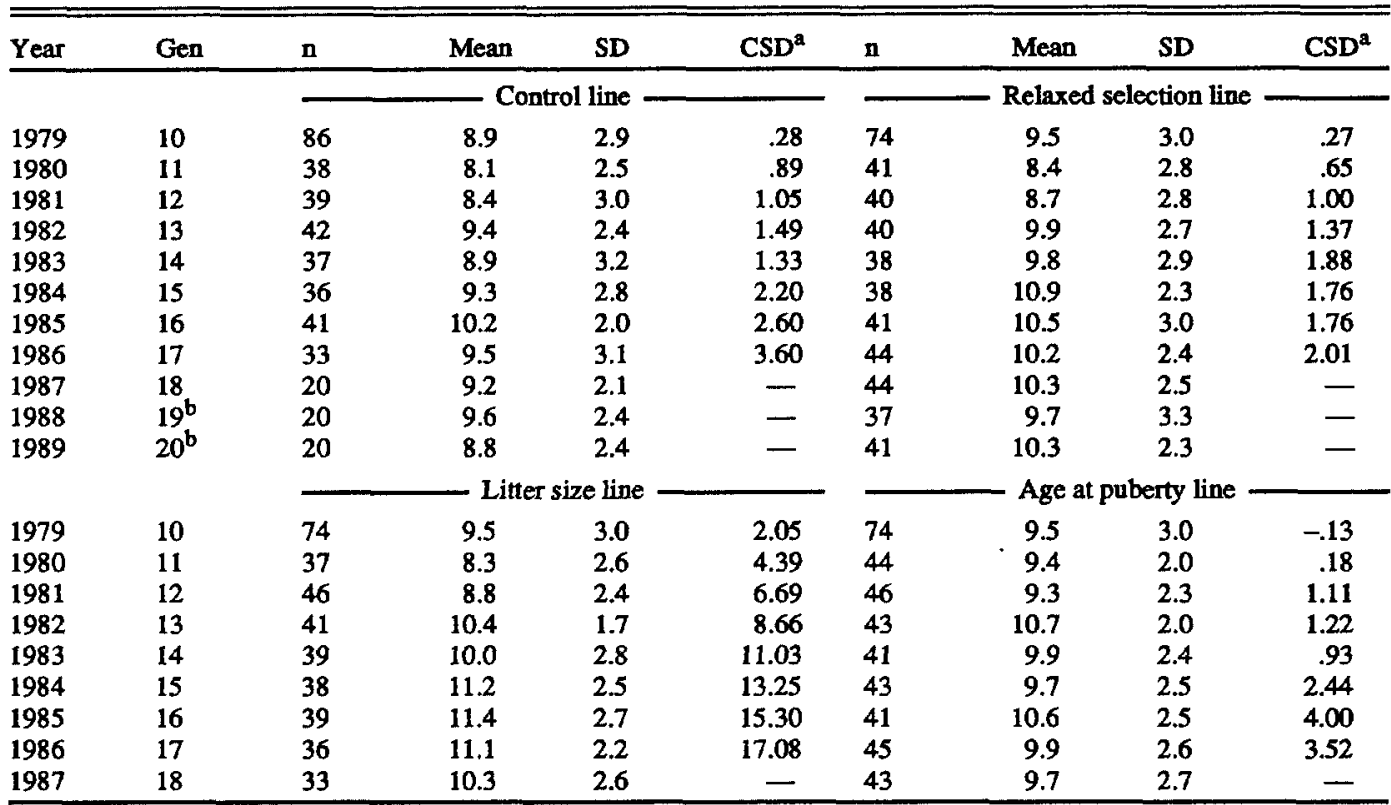

${ }^{2} \mathrm{CSD}=$ cumulative selection differential.

${ }^{b}$ Generations of random selection.

About $75 \%$ of the total response in ovulation rate at generation 9 in the OR line compared with the $\mathrm{C}$ line was maintained in the RS line during the period of random selection. This reduction in the difference between lines suggests that part of the increased ovulation rate was due to selection for effects of combinations of genes (epistasis). Selection must be continued to maintain combinations of genes with positive effects unless selection has fixed these genes in the population, quite unlikely for an experiment of this duration. Recombination of genes occurred in the RS line during the period of random selection and could have caused a reduction in the difference between the $R S$ and $C$ lines if epistatic gene effects were important.

The total response in litter size in the OR line was maintained in the RS line during the period of random selection. Thus, mean ovulation rate of the RS line was sufficiently high that a decrease of one egg in the difference between the RS and C lines did not cause a reduction in the difference in litter size. Twenty percent of the additional ovulations due to genetic selection were represented by a pig at birth during the selection phase, and $26 \%(.74 / 2.86)$ of the increase in ovulation rate maintained during random selection was represented by a pig at birth.

Fifteen generations of random selection within litters followed 15 generations of selection for ovulation rate in mice (Bradford, 1979). Litter size increased significantly during this period, but this response was due to divergence between lines that occurred from generations 25 to 30 . Bradford (1979) suggested that natural selection among embryos after implantation resulted in improvement in genetic potential for prenatal survival and caused the improvement in litter size. The increase in litter size during a period of random selection following selection for ovulation rate observed in mice was not evident in our experiment with swine.

Effects of genetic increases in ovulation rate on litter size observed in this experiment are similar to results of other methods of increasing the potential number of viable embryos. For example, superinduction (Longenecker and Day, 1968; Lamberson and Day, 1986) has not resulted in substantially increased litter size past $40 \mathrm{~d}$ of gestation.

Selection for increased ovulation rate has increased litter size. The "success" of the experiment might better be measured not by 
the increase in litter size relative to the change in ovulation rate, but rather by the increase in litter size from this method relative to other methods of selection. Johnson et al. (1984) predicted that response to direct selection for litter size would be .12 pigs per generation in a population of similar size to that used in our experiment. Observed response to selection for ovulation rate was about $75 \%$ of this value.

Direct Selection for Increased Litter Size. An important consideration in estimating response to selection for litter size in the highovulating line is whether the RS line changed genetically relative to the $C$ line. If it did, the RS line is the proper control for the LS line; if not, both the RS and C lines can be used as controls.

Direct selection for increased litter size was practiced for eight generations in the line previously selected for ovulation rate. Two generations of random selection separated the two phases. During the period of random selection, litter size increased more in the RS line than in the $\mathrm{C}$ line. However, the rate of increase was not significant (Figure 2). There also was an upward trend in predicted breeding values for both lines during this period (Figure 3). Regressions of breeding values on generation were .044 for the $C$ line and .097 for the
RS line. The difference between these regressions gives an average change of .053 pigs per generation, similar to the value of .033 obtained from regression of line means on generation number.

We chose to use both the RS and C lines as controls to measure response in the LS line for three reasons. First, differences between the RS and $C$ lines were not consistent across generations and the difference between regressions of line means on generation was not significant. Second, we are not able to propose a biological model to explain an increase in litter size during the period of relaxed selection for ovulation rate. It would be during early generations after selection is relaxed that a population would likely change due to either loss of favorable epistatic combinations (Griffing, 1960) or recovery from effects of opposing natural selection. However, differences between the RS and C lines were quite similar during the first five generations of relaxed selection and the positive trend was influenced largely by differences in generations 15,18 , and 20 (Figure 2). Third, realized selection differentials in both the RS and C lines were nearly identical (Table 2). Because withinfamily selection was used, there was little opportunity for natural selection to change

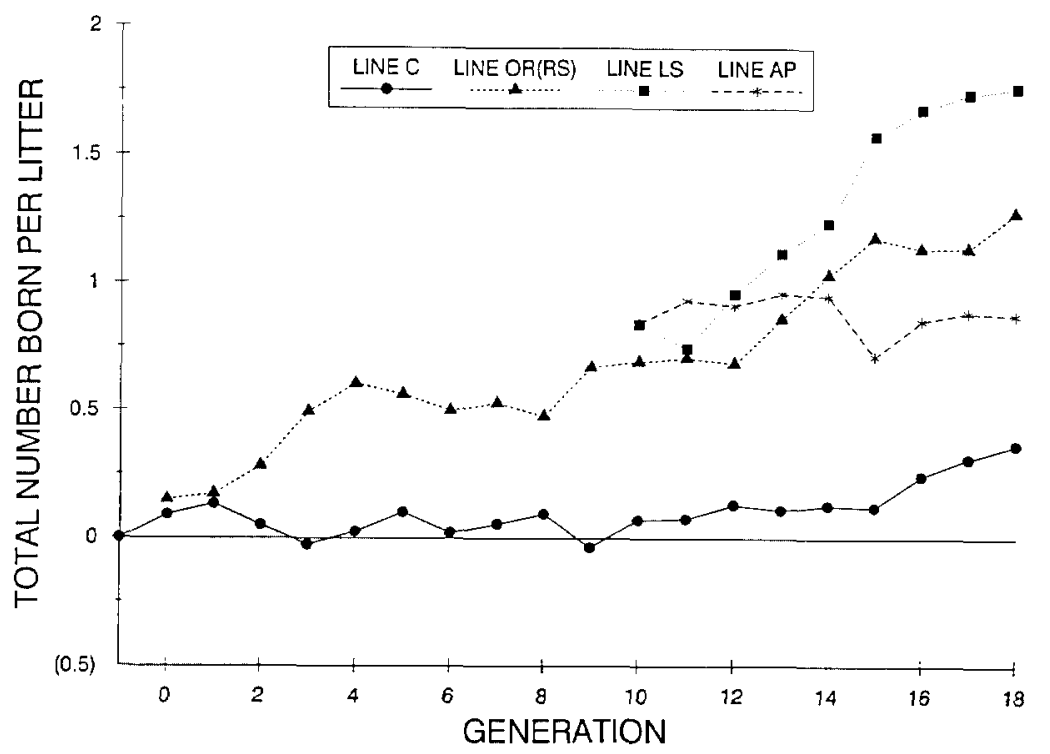

Figure 3. Best linear unbiased predictions of mean genetic value for litter size for ovulation rate (OR) and control lines (C) during period of selection for OR, generations -1 to 9, or subsequent period of relaxed selection (RS), or selection for increased litter size (LS), or decreased age at puberty (AP). 
TABLE 3. MEAN INBREEDING COEFFICIENTS BY LINE ASSUMING GENERATION-10 PROGENY AS BASE

\begin{tabular}{|c|c|c|c|c|c|c|c|c|c|}
\hline \multicolumn{2}{|c|}{ Generation } & \multicolumn{2}{|c|}{ Control } & \multicolumn{2}{|c|}{$\begin{array}{l}\text { Relaxed } \\
\text { selection }\end{array}$} & \multicolumn{2}{|c|}{$\begin{array}{c}\text { Litter } \\
\text { size }\end{array}$} & \multicolumn{2}{|c|}{$\begin{array}{c}\text { Age } \\
\text { at puberty }\end{array}$} \\
\hline Progeny & Dams & Progeny & Dams & Progeny & Dams & Progeny & Dams & Progeny & Dams \\
\hline 11 & 10 & 0 & 0 & 0 & 0 & 0 & 0 & 0 & 0 \\
\hline 12 & 11 & 1.3 & 0 & .9 & 0 & .9 & 0 & .9 & 0 \\
\hline 13 & 12 & 2.1 & 1.3 & 2.3 & .9 & 3.3 & .9 & 1.8 & .9 \\
\hline 14 & 13 & 2.3 & 1.7 & 3.6 & 2.7 & 4.7 & 2.5 & 2.8 & 2.0 \\
\hline 15 & 14 & 3.5 & 2.1 & 4.4 & 3.0 & 7.0 & 4.9 & 4.6 & 2.7 \\
\hline 16 & 15 & 4.8 & 3.8 & 5.3 & 4.3 & 6.5 & 7.1 & 6.2 & 4.2 \\
\hline 17 & 16 & 5.2 & 4.6 & 6.5 & 5.4 & 8.7 & 7.1 & 5.9 & 6.3 \\
\hline 18 & 17 & 6.4 & 5.4 & 6.8 & 6.4 & 10.3 & 8.5 & 7.1 & 5.3 \\
\hline 19 & 18 & 7.4 & 6.4 & 7.2 & 6.7 & 11.7 & 10.3 & 7.2 & 7.0 \\
\hline $19^{\mathrm{a}}$ & $\ldots$ & 14.5 & - & 14.9 & - & 19.1 & - & 15.2 & - \\
\hline
\end{tabular}

${ }^{2}$ Inbreeding of generation-19 progeny calculated from generation 0 .

uterine capacity or embryo survival in the RS line.

Descriptive statistics for litter size are presented in Table 2. Litter size increased in all lines from generations 10 to 18 . Cumulative standardized selection differentials were 1.32 , $.74,6.26$, and 1.29 for the C, RS, LS, and AP lines, respectively.

Inbreeding accumulated most rapidly in the LS line, and rate of inbreeding was similar for other lines during the second phase of the experiment (Table 3). Mean inbreeding for generation- 11 progeny was $5.9 \%$ for the $C$ line and $6.3 \%$ for the (OR/RS) line when calculated from a base of generation 0 in 1967. Over the entire experiment, mean inbreeding of generation-19 progeny ranged from $14.5 \%$ for the $\mathrm{C}$ line to $19.1 \%$ for the LS line.

The regression of response in LS on cumulative selection differential was $.074 \pm$ .023 pigs; the realized heritability was $.15 \pm$ .05. Environmental effects, assumed to be equal for the LS, RS, and C lines, and genetic response to eight generations of selection, predicted as $.5 h^{2} \times C S D$, for each line are plotted in Figure 4. Response in litter size to eight generations of selection was estimated to be 1.06 pigs, twice as large as the increase of .48 pigs in predicted breeding value for the LS line compared with the mean of the RS and C lines (Figure 3).

Results of the only other selection experiment in which several generations of selection for litter size in swine was practiced were reported by Ollivier and Bolet (1981), Ollivier (1982), and Bolet et al. (1989). Early results were promising, but after 11 generations select and control lines differed very little. Realized heritability was $.04 \pm .13$ for the mean litter size of the dam's first two litters, the criterion of selection. Selection in our experiment was in a high-ovulating line, whereas they practiced selection in a population previously unselected for ovulation rate. Selection pressure on component traits may have been different in the two experiments; this could have caused responses to differ (Johnson et al., 1984; Bennett and Leymaster, 1989). Furthermore, delayed puberty of gilts in the experiment conducted in France caused substantially fewer litters than planned for in some generations and selection differentials were lower than expected (Ollivier and Bolet, 1981). They introduced some outside stocks into the lines midway through the experiment to correct the problem. Thus, important differences between the experiment done in France and our experiment hinder interpretations of the different results.

Age at Puberty. Descriptive statistics for age at puberty are given in Table 4. Regressions of line means on generation number are shown in Figure 5, and genetic and environmental trends, calculated from results of analysis by the method of Richardson et al. (1968), are shown in Figure 6.

Age at puberty steadily decreased over eight generations of selection. The response was $-1.64 \pm .72 \mathrm{~d}$ per generation in the RS line and $-3.32 \pm .29 \mathrm{~d}$ in the AP line (Figure 5).

Environmental effects became smaller over generations, and there was a large negative 
TABLE 4. DESCRIPTIVE STATISTICS FOR AGE AT PUBERTY BY LINE AND GENERATION (GEN)

\begin{tabular}{|c|c|c|c|c|c|c|c|c|c|}
\hline \multirow[b]{2}{*}{ Year } & \multirow[b]{2}{*}{ Gen } & \multicolumn{4}{|c|}{ Relaxed selection line } & \multicolumn{4}{|c|}{ Age at puberty line } \\
\hline & & $\mathbf{n}$ & Mean & SD & $\mathrm{CSD}^{\mathrm{a}}$ & $\mathbf{n}$ & Mean & SD & CSD \\
\hline 1979 & 11 & 51 & 174.1 & 26.8 & -1.6 & 86 & 174.4 & 26.7 & -17.1 \\
\hline 1980 & 12 & 48 & 176.7 & 25.8 & -.9 & 145 & 175.0 & 21.7 & -35.9 \\
\hline 1981 & 13 & 59 & 179.0 & 25.9 & -8.4 & 136 & 171.7 & 22.2 & -54.2 \\
\hline 1982 & 14 & 56 & 178.6 & 24.2 & -13.3 & 146 & 169.8 & 22.3 & -73.7 \\
\hline 1983 & 15 & 97 & 179.4 & 30.3 & -14.8 & 132 & 168.1 & 23.6 & -92.1 \\
\hline 1984 & 16 & 55 & 171.2 & 23.9 & -21.5 & 149 & 161.9 & 24.2 & -114.6 \\
\hline 1985 & 17 & 56 & 167.6 & 22.3 & -23.9 & 181 & 160.3 & 23.8 & -136.9 \\
\hline 1986 & 18 & 55 & 173.1 & 29.6 & -29.0 & 156 & 153.0 & 23.2 & -153.0 \\
\hline 1987 & 19 & 42 & 158.5 & 21.6 & - & 134 & 150.2 & 22.3 & - \\
\hline
\end{tabular}

acCumulative selection differential.

environmental effect in the last generation, which explains the large reduction in age at puberty in the RS line in generation 19 (Figures 5 and 6). The regression of response on cumulative selection differential was $.126 \pm$ .026 ; the realized heritability was $.25 \pm .052$. This corresponds closely to the realized heritability of $.24 \pm .28$ reported by Hixon et al. (1987), who practiced bidirectional selection for age at puberty for one generation. The genetic difference between lines was estimated to be $15.7 \mathrm{~d}$ in generation 19 .
Best linear unbiased predictions of mean age at puberty for the AP and RS lines are illustrated in Figure 7. The predicted difference between the AP and RS lines was -17.1 $\mathrm{d}$ in generation 19, in quite good agreement with the response obtained from the analysis by Richardson's method.

Selection for age at puberty was effective. No genetic changes in litter size from this selection were apparent (Figure 3). Secondary selection differentials for litter size in the AP line were similar to those for litter size in the

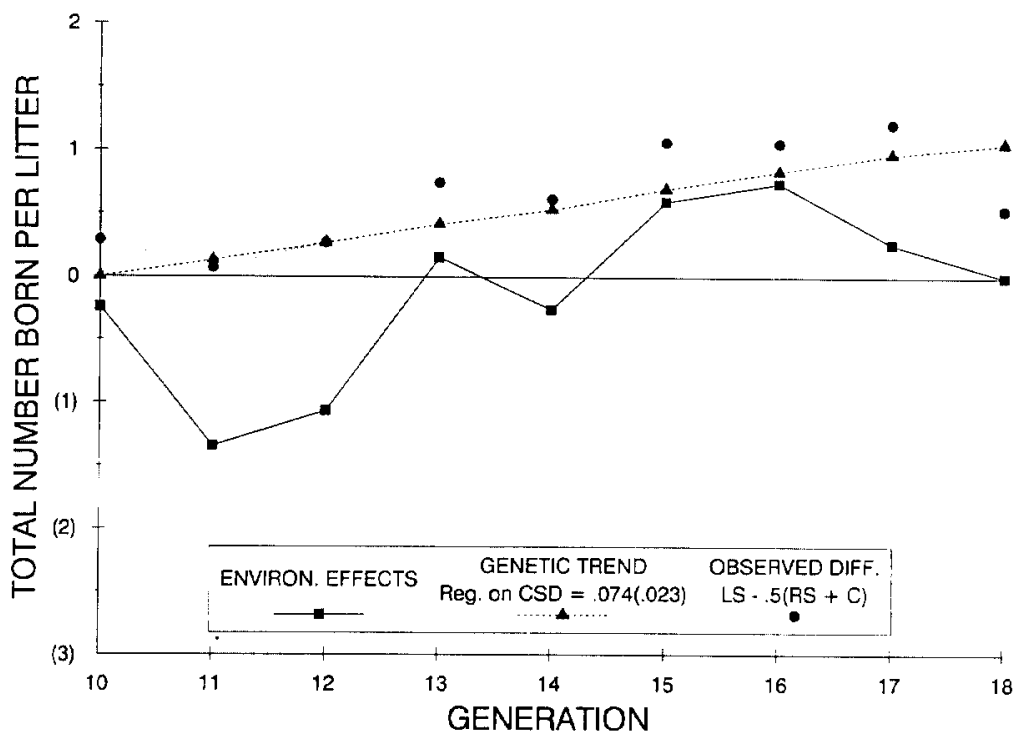

Figure 4. Environmental effects and predicted genetic response in the LS line from analysis of litter size by the method of Richardson et al. (1968) and observed difference between the LS and the mean of the RS and C lines. Genetic trend was calculated as the regression of response on cumulative selection differential (CSD) $\times$ CSD and expressed as a deviation of the LS line from the mean of the RS and C lines. $(L S=$ litter size, RS = relaxed selection, and C = control) 
$\mathrm{C}$ and RS lines (Table 1), so no artificial selection occurred for litter size when selecting for decreased age at puberty.

Drickamer (1981) reported results of six generations of selection for age at sexual maturation, measured by age of first vaginal estrus, in four lines of mice. Realized heritabilities ranged from .32 to .58 for the four lines. In a subsequent investigation of these lines, Drickamer (1983) found that litter size, survival of pups, and fertility were not affected by selection for age at sexual maturation.

Our results with swine agree with those for mice, but realized heritability was lower in swine. Similarly, realized heritability for age at puberty was about half as large as the estimate of .53 obtained from the sire component of variance using data from the first selection phase of this experiment (Young et al., 1978). Young and coworkers also obtained very small estimates of genetic correlations of age at puberty with ovulation rate and litter size. Lack of change in litter size from selection for age at puberty in our experiment supports the earlier findings. As in the mouse, age at puberty and litter size seem not to be genetically correlated.

The distributions of age at puberty for the AP and RS lines in generation 19 (1987) and for both lines in generation 11 (1979, base generation) are shown in Figure 8. Selection did not reduce the variation in age at puberty in later generations (Table 4). The distribution of age at puberty was slightly skewed; selection simply reduced the mean of the distribution and did not change its shape.

Mixed-Model Analyses. Estimates of heritability, proportion of variance due to nonadditive genetic and environmental effects common to litters, and phenotypic standard deviations obtained from mixed-model analyses are shown in Table 5. Within-line analyses were done by the methods of pseudo-expectation and REML for litter size, but only by pseudo-expectation for age at puberty. Estimates obtained by regression of daughter on dam are presented for comparison purposes.

Except for litter size in the LS line during generations of selection for litter size, estimates of heritability by the various methods agree quite well. The pseudo-expectation and REML methods gave similar estimates in populations randomly selected, but selection may cause estimates obtained by pseudoexpectation to be biased downward (Van Raden and Jung, 1988).

The REML method produced an estimate of heritability of litter size of .07 in the LS line, one-half the realized heritability of .15 . However, the average of estimates of heritability

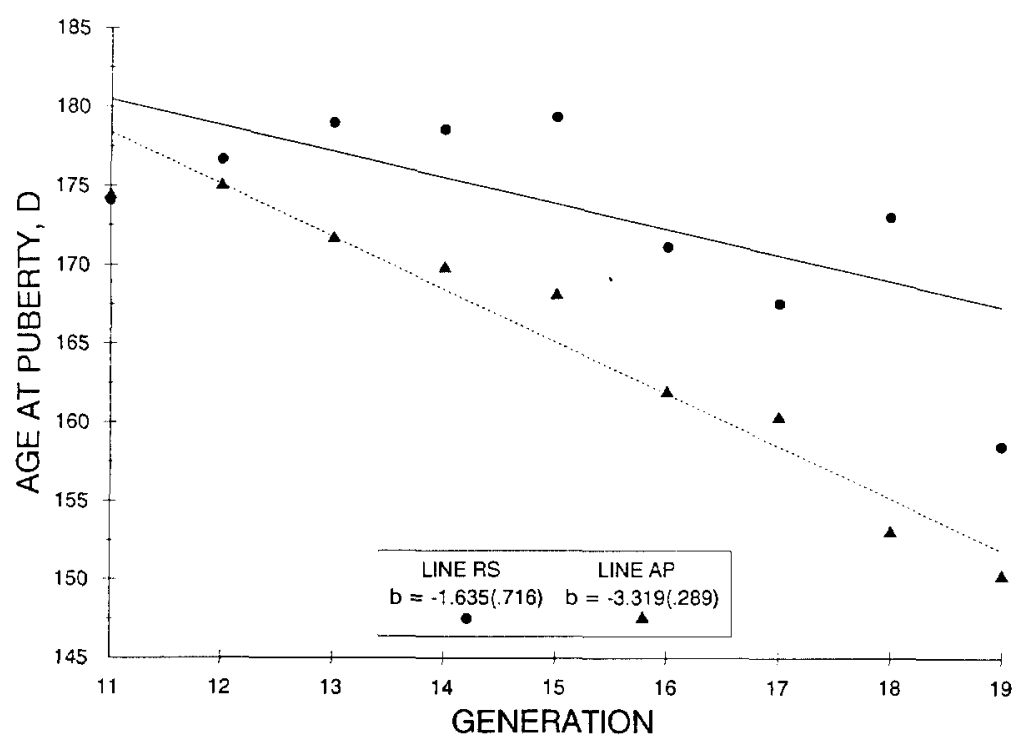

Figure 5. Means and regressions of means on generation for age at puberty from generations 11 to 19 (RS = relaxed selection, $A P=$ age at puberty). 


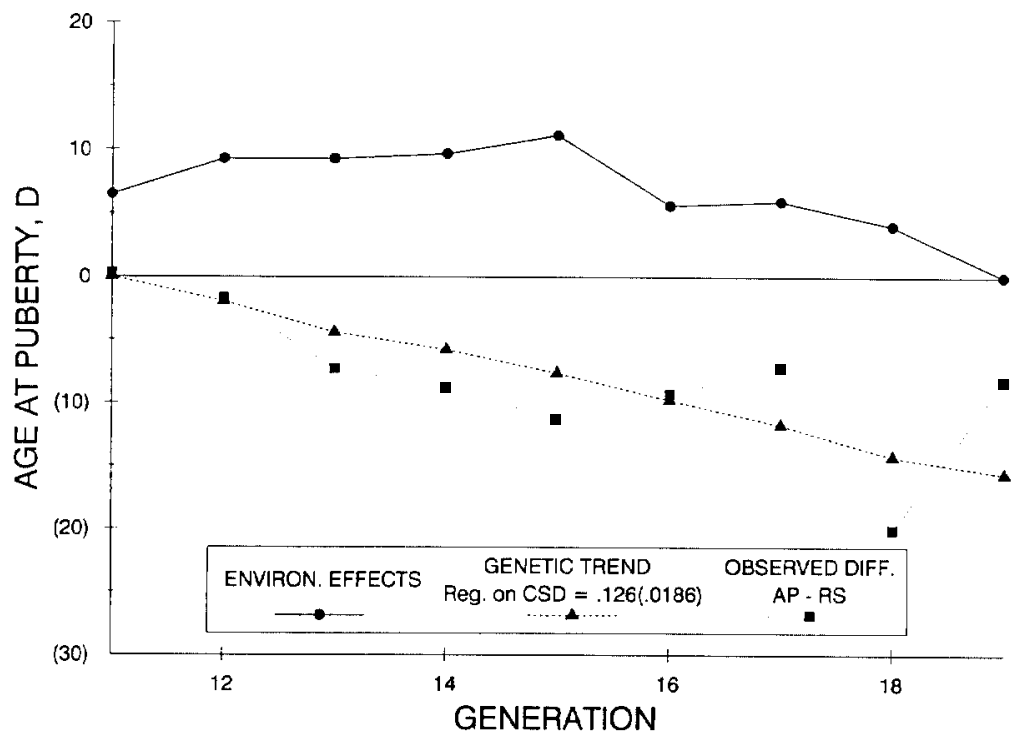

Figure 6. Environmental effects and predicted genetic response in the age at puberty (AP) line expressed as a deviation from the relaxed selection (RS) line from analysis by the method of Richardson et al. (1968) and observed difference between the AP and RS lines. Genetic trend was calculated as the regression of response on cumulative selection differential (CSD) $\times$ CSD.

for the C, RS, and LS lines obtained by REML lower. All other estimates were essentially nil. was .13.

The method of pseudo-expectation gave fairly large estimates of $c^{2}$ for the LS and AP lines, but estimates by REML were much

Daughter-dam regression estimates of heritability of litter size agreed well with other estimates, except for the LS line. Because selection caused there to be little variation

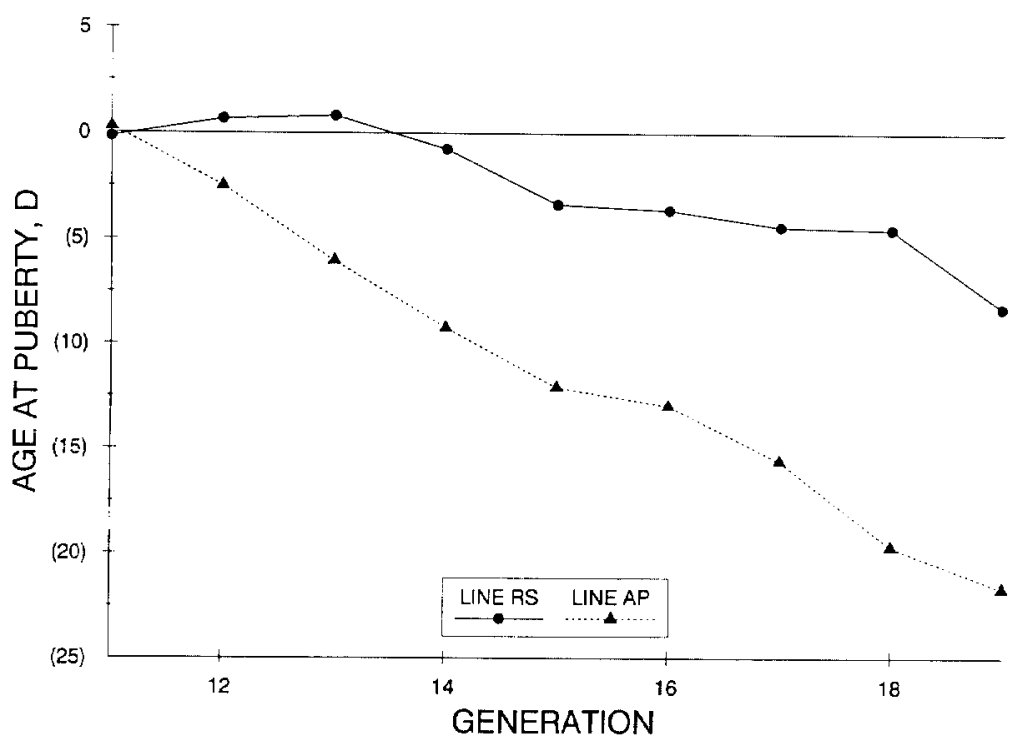

Figure 7. Best linear unbiased predictions of mean genetic value for age at puberty (AP) and relaxed selection (RS) lines. 
among dams in the LS line, this estimate has a large standard error. Although unbiased, daughter-dam regression probably will not produce precise estimates of heritability in populations undergoing moderate to intense selection for litter size.

The method of pseudo-expectation produced similar estimates of heritability of age at puberty for each line. The estimate was lowest for the AP line, which was undergoing direct selection for the trait. The average of values obtained by pseudo-expectation for the AP and RS lines was .23, very similar to the realized heritability of .25 .

Variance in age at puberty due to common litter effects was large and averaged $13 \%$ for the RS and AP lines during the second phase of the experiment. Several environmental factors probably contributed to this effect. Most important of these likely was the tendency for sisters to be penned together until they had been observed to be in estrus.
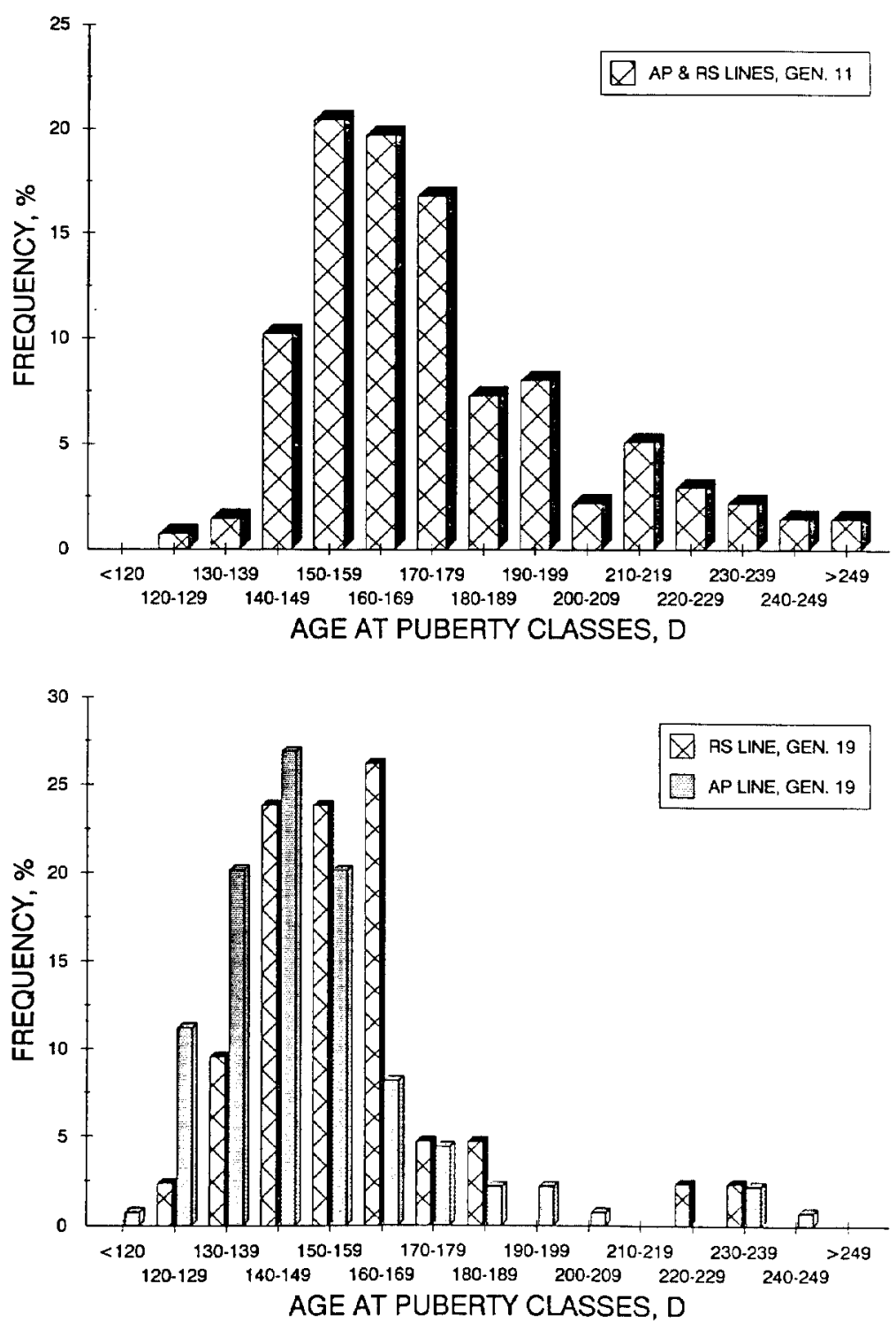

Figure 8. Distribution of age at puberty for all gilts in generation 11 (AP and RS lines in 1979) and for gilts from age at puberty (AP) and relaxed selection (RS) line gilts in generation 19 (1987). 
TABLE 5. ESTIMATES OF HERITABILITY $\left(\hat{\mathrm{h}}^{2}\right)$, PROPORTION OF VARIANCE DUE TO COMMON LTTTER EFFECTS $\left(\hat{c}^{2}\right)$, AND PHENOTYPIC STANDARD DEVIATION $(\hat{\partial})$ FROM MIXED-MODEL ANALYSES ${ }^{\mathrm{a}}$

\begin{tabular}{|c|c|c|c|c|c|}
\hline Trait, method, and lines ${ }^{\mathfrak{c}}$ & $\begin{array}{l}\text { Generations } \\
\text { of data }\end{array}$ & $\left(\hat{\mathrm{h}}^{2}\right)$ & $\left(\mathrm{c}^{2}\right)$ & $(\hat{\theta})$ & $\hat{\mathbf{h}}_{\mathrm{dd}}^{2 \mathrm{~b}}$ \\
\hline \multicolumn{6}{|l|}{ Litter size } \\
\hline \multicolumn{6}{|l|}{ Pseudo-expectations } \\
\hline All & 0 to 18 & .18 & .002 & 2.66 & .18 \\
\hline All & 10 to 18 & .21 & .004 & 2.60 & .20 \\
\hline C & 0 to 18 & .15 & .000 & 2.64 & .12 \\
\hline RS & 0 to 18 & .19 & .001 & 2.86 & .19 \\
\hline LS & 101018 & .00 & .120 & 2.55 & -.17 \\
\hline $\mathbf{A P}$ & 10 to 18 & .09 & .07 & 2.49 & .21 \\
\hline \multicolumn{6}{|l|}{ REML } \\
\hline C & 10 to 18 & .15 & .000 & 2.60 & - \\
\hline RS & 10 to 18 & .17 & .000 & 2.83 & - \\
\hline LS & 10 to 18 & .07 & .045 & 2.73 & - \\
\hline $\mathbf{A P}$ & 10 to 18 & .10 & .024 & 2.72 & - \\
\hline \multirow{2}{*}{\multicolumn{6}{|c|}{$\begin{array}{l}\text { Age at puberty, } d \\
\text { Pseudo-expectations }\end{array}$}} \\
\hline & & & & & \\
\hline RS & 0 to 19 & .26 & .21 & 20.5 & .43 \\
\hline RS & 11 to 19 & .32 & .10 & 26.5 & .47 \\
\hline AP & 11 to 19 & .20 & .16 & 23.3 & .89 \\
\hline RS and AP & 0 to 19 & .32 & .16 & 24.3 & .46 \\
\hline
\end{tabular}

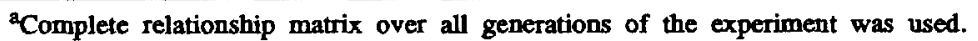

baughter-dam regression estimate.

${ }^{{ }^{c} \mathrm{C}}=$ control, $\mathrm{RS}=$ relaxed selection, $\mathrm{LS}=$ litter size, and $\mathrm{AP}=$ age at puberty.

Movement of pigs was based on age. Thus, sisters were often penned together in the nursery and were often in the same or adjacent pens in the modified open-front buildings. Exposure to boars also was initiated on the same day for most sisters. Thus, preweaning environmental effects common to sisters, such as size of litter in which gilts were raised, are confounded with those induced by postweaning management in this experiment.

Estimates of heritability of age at puberty from daughter-dam regression were much higher than those obtained from pseudoexpectation or the realized heritability. The explanation for this finding is not clear.

\section{Impilications}

Ovulation rate, litter size, and age at puberty can be changed by selection. Selection for only ovulation rate, however, is not an efficient way to increase litter size. Because litter size is lowly heritable, response to selection will likely be quite erratic from one generation to the next unless population size is large, but responses close to those predicted from estimates of heritability should be realized. Age at puberty will respond to selection.
No accompanying changes in litter size are expected. The long-term effects of changes in age at puberty on reproductive efficiency of the sow herd need to be evaluated.

\section{Literature Cited}

Bennett, G. L. and K. A. Leymaster. 1989. Integration of ovulation rate, potential embryonic viability and uterine capacity into a model of litter size in swine. $J$. Anim. Sci. 67:1230.

Bolet, G., L. Ollivier and P. Dando. 1989. Sélection sur la prolificité chez le porc. I. Résultats d'une experience de sélection sur onze genérations. Genet. Sel. Evol. 21 : 93.

Bradford, G. E. 1968. Selection for litter size in mice in the presence and absence of gonadotropin treatment. Genetics 58:283.

Bradford, G. E. 1969. Genetic control of ovulation rate and embryo survival in mice. I. Response to selection. Genetics 61:905.

Bradford, G. E. 1979. Genetic variation in prenatal survival and litter size. J. Anim. Sci. 49(Suppl. 2):66.

Cunningham, P. J., M. E. England, L. D. Young and D. R. Zimmerman. 1979. Selection for ovulation rate in swine: Correlated response in litter size and weight. J. Anim. Sci. 48:509.

Drickamer, L. C. 1981. Selection for age of sexual maturation in mice and the consequences for population regulation. Behav. Neural Biol. 31:82.

Drickamer, L. C. 1983. Mice selected for age at puberty: Reverse selection and reproductive characteristics. Biol. Reprod. 28:843. 
Falconer, D. S. 1971. Improvement of litter size in a strain of mice at a selection limit. Genet. Res. 17:215.

Griffing, B. 1960. Theoretical consequences of truncation selection based on the individual phenotype. Aust. J. Biol. Sci. 13:307.

Hill, W. G. 1972. Estimation of realized heritabilities from selection experiments. II. Selection in one direction. Biometrics 28:767.

Hill, W. G. 1977. Variation in response to selection: In: E. Pollak, O. Kempthorne and T. B. Bailey (Ed.) Proc. Int. Conf. Quant. Genet. pp 343-365. Iowa State Univ., Ames.

Hix on, A. L., J. W. Mabry, L. L. Benyshek, W. M. Weaver and M. A. Marks. 1987. Estimates of genetic parameters for sexual and compositional maturity in gilts. J. Anim. Sci. 64:977.

Joakimsen, O. and R. L. Baker. 1977. Selection for litter size in mice. Acta Agric. Scand. 27:301.

Johnson, R. K., R. A. Pumfrey, A.P.K. Jones and D. R. Zimmerman. 1981. Embryo and fetal loss in gilts differing in ovulation rate. J. Anim. Sci. 53(Suppl. 1): 74 (Abstr.).

Johnson, R. K., D. R. Zimmerman and R. J. Kittok. 1984. Selection for components of reproduction in swine. Livest. Prod. Sci. 11:541.

Kelly, C. R., J. D. Kopf and D. R. Zimmerman. 1988. Characterization of antral follicle populations during the estrous cycle in pigs selected for ovulation rate. J. Anim. Sci. 66:1230.

Koenig, J. L. Farver. 1987. Cytogenetic analysis of swine ova: The effect of superovulation and selection for high ovulation rate. Ph.D. Dissertation. Univ. of Nebraska, Lincoln.

Lamberson, W. R. 1984. Selection for reproductive traits in swine. Ph.D. Dissertation. Univ. of Nebraska, Lincoln.

Lamberson, W. R. and B. N. Day. 1986. Response to selection for increased superovulation rate in swine.
Proc. 3rd World Congr. on Genet. Appl. to Livest. Prod. 11:249.

Land, R. B. and D. S. Falconer. 1969. Genetics of ovulation rate in the mouse. Genet. Res. 13:25.

Longenecker, D. E. and B. N. Day. 1968. Fertility level of sows superovulated at post-weaning estrus. J. Anim. Sci. 27:709.

Ollivier L. 1973. Five generations of selection for increasing litter size in swine. Genetics 74(Suppl. 2):202.

Ollivier, L. 1982. Selection for prolificacy in the pig. Pig News Info. 3:383.

Ollivier, L. and G. Bolet. 1981. La sélection sur la prolificité chez le porc: Résultats d'une expérience de sélection sur dix gentrations. Journ. Rech. Porcine Fr. 13:261.

Patterson, H. D. and R. Thompson. 1971. Recovery of interblock information when block sizes are unequal. Biometrika 58:545.

Richardson, R. H., K. Kojima and H. L. Lucas. 1968. An analysis of short term selection experiments. Heredity 23:493.

Schaeffer, L. R. 1986. Pseudo expectation approach to variance component estimation. J. Dairy Sci. 69:2884.

Tess, M. W., G. L. Bennett and G. E. Dickerson. 1983. Simulation of genetic changes in life cycle efficiency of pork production. II. Effects of components on efficiency. J. Anim. Sci. 56:354.

Van Raden, P. M. and Y. C. Jung. 1988. A general purpose approximation to restricted maximum likelihood: The tilde-hat approach. J. Dairy Sci. 71:187.

Young, L. D., R. A. Pumfrey, P J. Cunningham and D. R. Zimmerman. 1978. Heritabilities and genetic and phenotypic correlations for prebreeding traits, reproductive traits and principal components. J. Anim. Sci. 46:937.

Zimmerman, D. R. and P. J. Cunningham. 1975. Selection for ovulation rate in swine: Population, procedures and ovulation response. J. Anim. Sci. 40:61. 